\title{
ELECTROPHYSIOLOGICAL INVESTIGATION FOR AUTONOMIC DYSFUNCTION IN PATIENTS WITH MYASTHENIA GRAVIS: A PROSPECTIVE STUDY
}

\author{
Mecbure NALBANTOGLU', Mehmet Ali AKALIN² ${ }^{2}$ Aysegul GUNDUZ ${ }^{3}$, Meral KIZILTAN ${ }^{3}$ \\ 'Demiroglu Bilim University Medical Faculty, Neurology Department, Istanbul, Turkey \\ ${ }^{2}$ Memorial Bahcelievler Hospital, Neurology Department, Istanbul, Turkey \\ ${ }^{3}$ Istanbul University Cerrahpasa Medical Faculty, Neurology Department, Istanbul, Turkey
}

Background and purpose - Myasthenia gravis (MG) is an autoimmune disorder of neuromuscular transmission. Autonomic dysfunction is not a commonly known association with MG. We conducted this study to evaluate autonomic functions in MG \& subgroups and to investigate the effects of acetylcholinesterase inhibitors.

Methods - This study comprised 30 autoimmune MG patients and 30 healthy volunteers. Autonomic tests including sympathetic skin response (SSR) and R-R interval variation analysis (RRIV) was carried out. The tests were performed two times for patients who were under acetylcholinesterase inhibitors during the current assessment. Results - The RRIV rise during hyperventilation was better $(p=0.006)$ and Valsalva ratio $(p=0.039)$ was lower in control group. The SSR amplitudes were lower thereafter drug intake $(p=0.030)$. As much as time went by after drug administration prolonged SSR latencies were obtained ( $p=0.043)$.Valsalva ratio was lower in the AchR antibody negative group $(p=0.033)$.

Conclusion - The findings showed that both ocular/generalized MG patients have a subclinical parasympathetic abnormality prominent in the AchR antibody negative group and pyridostigmine has a peripheral sympathetic cholinergic noncumulative effect.

Keywords: myasthenia gravis, autonomic dysfunction, sympathetic skin response, $R-R$ interval variation analysis, anticholinesterase inhibitors, pyridostigmine

\author{
MYASTHENIA GRAVIS-BETEGEK AUTONÓM \\ RENDELLENESSÉGEINEK ELEKTROFIZIOLÓGIÁS \\ VIZSGÁLATA: PROSPEKTÍV TANULMÁNY \\ Nalbantoglu M, MD; Akalin MA, MD; Gunduz A, MD; \\ Kiziltan $M, M D$ \\ Ideggyogy Sz $2021 ; 74(1-2): 33-40$.
}

Háttér és cél - A myasthenia gravis (MG) a neuromuscu laris junctio autoimmun típusú megbetegedése. Az autonóm rendellenességeket nem gyakran társítják myasthenia gravishoz. A vizsgálat célja az volt, hogy megállapítsuk, milyen autonóm múködés jellemzi az MG-betegek különböző alcsoportjait, és megvizsgáljuk az acetilkolinészterázinhibitorok hatásait.

Módszerek - A vizsgálatba 30 autoimmun MG-beteget és 30 egészséges önkéntest vontunk be. Az autonóm múködés tesztelése érdekében szimpatikus bőrreakció (SSR) és $R-R$ intervallumvariáció analízis (RRIV) vizsgálatokat végeztünk. Az acetilkolinészteráz-inhibitor-kezelésben részesülő betegek körében kétszer végeztük el a vizsgálatokat.

Eredmények - Az RRIV hiperventiláció alatti növekedése nagyobb $(p=0,006)$ és a Valsalva-arány alacsonyabb $(p=0,039)$ volt a kontrollcsoport tagiainál. Az SSR-amplitúdók alacsonyabbak voltak a gyógyszer bevétele után $(p=0,030)$. A gyógyszer bevétele után eltelt idő növekedésével megnyúlt SSR-látenciákat kaptunk ( $p=0,043)$. A Valsalva-arány alacsonyabb volt az AchR antitestre negatív csoportban ( $p=0,033)$.

Következtetés - Mind az okuláris, mind a generalizált MG-betegek körében szubklinikus paraszimpatikus rendellenesség mutatható ki, különösen az AchR antitestre negatív csoportban. A piridostigmin perifériás szimpatikus kolinerg nonkumulatív hatással rendelkezik.

Kulcsszavak: myasthenia gravis, autonóm diszfunkció, szimpatikus bőrreakció, $R-R$ intervallumvariáció analízis, antikolinészteráz-inhibitorok, piridosztigmin

Correspondent: Dr. Mecbure NALBANTOGLU, Demiroglu Bilim University Medical Faculty, Neurology Department, Istanbul, Turkey.

Phone: 05069097109, fax: 02122244982, e-mail: mecbure03@hotmail.com https://orcid.org/0000-0002-1131-887X

Érkezett: 2019. december 10. Elfogadva: 2020. augusztus 4. 
M yasthenia gravis (MG) is an autoimmune disorder of the neuromuscular transmission caused by antibodies against nicotinic acetylcholine receptors (AchR). Muscle specific tyrosine kinase (MuSK) initiates aggregation of AchRs at the muscle endplate. Seropositive MG defines disease with circulating antibodies against $\mathrm{AchR}$ or $\mathrm{MuSK}^{1}$. MG presents with a clinical history and examination findings of fluctuating and fatigable weakness of specific muscle groups. A clinical diagnosis may be confirmed by electrophysiological tests that demonstrate postsynaptic neuromuscular junction disorder and serological demonstration of AchR or MuSK antibodies $^{2-5}$.

Autonomic dysfunction is not a commonly known association with MG. There are however rare case reports of MG coexisting with autonomic failure in the literature ${ }^{6-8}$. Although the prominent feature in most of these cases was gastrointestinal dysmotility and pseudo-obstruction, but also cardiovagal, autonomic neuropathy, pupillary dysfunction, sudomotor symptoms and panautonomic failure was reported ${ }^{9}$. MG and subacute autonomic failure are independently recognized as autoimmune disorders associated with antibodies against the nicotinic AChR of muscle or autonomic ganglia, respectively ${ }^{10}$. A previous work has demonstrated that autonomic ganglia from $\alpha 3$ AChRimmunized rabbits had electrophysiological features of postsynaptic failure of ACh transmission ${ }^{11}$. Vernino et. al described seven patients with MG and dysautonomia and proposed the hypothesis that autonomic symptoms in some of these patients might be a result of humoral autoimmunity against ganglionic $\mathrm{AChRs}^{6}$.

Another feature is that the acetylcholinesterase inhibitors used in the symptomatic treatment of MG cause an indirect cholinergic effect by extending the life span of acetylcholine secreted from the cholinergic nerve endings. As a result, acetylcholine accumulates in the synaptic gap. Because of this reason, anticholinesterases can excitate all the cholinergic receptors including muscarinic and nicotinic receptors of autonomic nervous system (ANS) and neuromuscular junctional cholinergic receptors $^{12}$. Therefore, it should be remembered that although postsynaptic acetylcholine receptor uptake is present in MG, but also the acetylcholinesterase inhibitors may cause autonomic symptoms.

To examine the ANS, SSR and RRIV tests are used. The neural control of RRIV depends on parasympathetic reflex and is regulated by the innate vagal innervation of the heart. The SSR test is a sympathetic nervous system assay study investigat-

\section{ABBREVIATIONS}

AchR: acetylcholine receptors

$\mathrm{Ag}-\mathrm{AgCl}$ : silver-silver chloride

ANS: autonomic nervous system

MG: myasthenia gravis

MuSK: muscle specific tyrosine kinase

RRIV: R-R interval variation analysis

SSR: sympathetic skin response

ing the involvement of small myelin $\mathrm{C}$ fibers. Some abnormalities can also be detected by these tests in patients who do not have any clinical dysautonomic findings and thus demonstrate subclinical dysautonomia $^{13-20}$.

The idea that possible subclinical autonomic dysfunction may be increased in these patients, especially during the myasthenic and cholinergic crisis periods, prompted us to conduct this study. We, therefore, conducted this study to evaluate autonomic functions electrophysiologically for MG patients and subgroups. At the same time, it was aimed to investigate the effects of acetylcholinesterase inhibitors on ANS.

\section{Patients and methods}

This study comprised 30 autoimmune MG patients [17 women (56.7\%), 13 men (43.3\%)] who were followed at Istanbul University-Cerrahpasa Medical Faculty Neurology Department Neuromuscular Diseases outpatient/inpatient clinics. 30 healthy volunteers [18 women (60\%), 12 men (40\%)] were included in the study as the control group. Because one patient did not participate in the pre-drug (pyridostigmine bromide) test, statistical analysis was performed through 29 patients. Our work has been approved by the Ethics Committee with decision number A-27, 07.05.2013. Information about the procedures was given and necessary approvals were obtained.

Baseline characteristics for each patient were recorded which included demographical data, onset age of the disease, clinical aspects, presence of antibodies, drug history and the dose of acetylcholinesterase inhibitors during the current assessment. All included patients were with a positive response to acetylcholinesterase inhibitors, older than 18 years, diagnosed by consecutive nerve stimulation and/or single fiber electromyography (EMG) electrophysiologically and/or immunological support. Exclusion criteria were the presence of another 
neurological disorder, psychiatric or internal disease, drug use, metal objects such as aneurysm clips, cochlear implants, bone plates, and pacemakers that will be contraindicated or may effect electrophysiological studies.

Electrophysiological studies were performed by the same investigator using an EMG device (Neuropack -MEB5504K, Nihon Kohden Corporation, Tokyo, Japan). The patient was in a quiet $24{ }^{\circ} \mathrm{C}-25$ ${ }^{\circ} \mathrm{C}$ temperature room, comfortable, awake with eyes closed, on the examination chart, while lying in a supine position.

Autonomic tests including SSR and RRIV was carried out for each patient. Pyridostigmine bromide (Mestinon) effect starts in 15-30 minutes, reaches a maximum in 1-2 hours, and has a half-life of 3-4 hours. The tests were performed two times for patients who were under acetylcholinesterase inhibitors during the current assessment: at the end of the longest period of time that may be drug-free according to the treatment scheme (4-24 h) and one hour after taking the drug. The results of patients were compared with age and gender-matched 30 normal subjects who were taken as the control group.

SSR recording procedure: After skin cleansing, silver-silver chloride $(\mathrm{Ag}-\mathrm{AgCl})$ superficial electrodes are pasted using a conductive paste; the active one into the palm, the reference to the back of the hand and the ground electrode on the forearm of the same extremity. Electrical stimulation was performed randomly with the aid of a stimulator on the skin to the median nerve at the opposite extremity wrist level. The duration of the stimulations was $0.1 \mathrm{~ms}$, the intensity kept 15 milliamps (mA). The frequency filter settings were set to 0.1 to $1000 \mathrm{~Hz}$, the sensitivity to 0.5 to 2 microvolts $(\mathrm{mV})$ to division (div), and the scan time to $1 \mathrm{sec} / \mathrm{div}$. Obtained SSR latencies were calculated in milliseconds (ms) measured with the help of a cursor from where the first deflection started. The peak to peak distance of the deflection was calculated as amplitude as $\mathrm{mV}$.

$R R I V$ recording procedure: After skin cleansing, $\mathrm{Ag}-\mathrm{AgCl}$ superficial electrodes are placed to the 4th or 5 th intercostal space using conductive paste. The ground electrode is placed on the sternum bone. No external stimulus was given during the recording. The recording sequence was done separately, during rest, during deep breathing (at a frequency of 6 hyperventilation per minute) and Valsalva maneuvers. Filter settings were $1-20 \mathrm{~Hz}$, sensitivity $100-$ $200 \mathrm{mV}$, scan time $0.5 \mathrm{sec}$. RRIV\% was calculated by subtracting the shortest R-R interval from the longest $\mathrm{R}-\mathrm{R}$ interval, dividing it by the average $\mathrm{R}-\mathrm{R}$ interval, and multiplying the obtained value by 100 .
[(RR maximum-RR minimum) x100/RR average]. Valsalva ratio was calculated as: V maximum / V minimum.

Data analyzes were performed using the SPSS 15.0 statistical software package. A chi-square test was used to compare the demographic and clinical characteristics of categorical qualities between healthy individuals and patient groups. Parameters obtained from SSR and RRIV tests were compared using the nonparametric Mann-Whitney U test. The Wilcoxon test was used to compare the drug-free and medicated periods. Correlation analyzes were performed for monitoring the interaction of clinical findings with electrophysiological data. Statistical significance was accepted as p 0.05 .

\section{Results}

The mean age of the patient group and the control group was calculated as $47.86 \pm 15.08$, and $44.1 \pm$ $14.64(\mathrm{p}=0.353)$, respectively. According to gender, $55.2 \%(\mathrm{n}=16)$ of the patient group and $60 \%(\mathrm{n}$ $=18)$ of the control group were females $(\mathrm{p}=0.708)$. According to the age of onset, 17 patients $(58.62 \%)$ were in the early-onset and $12(41.38 \%)$ were in the late-onset group. When the patients were grouped according to the involved muscles, $19(65.52 \%)$ were in the generalized and $10(34.48 \%)$ were in the ocular myasthenia groups. Of all patients, 15 $(51.73 \%)$ were positive for AchR antibody, while $11(37.93 \%)$ of them were negative; $3(10.34 \%)$ had no AchR antibody result. In the AchR antibody positive group, 11 were generalized and 4 were in the ocular subgroup; in the AchR antibody negative group, 6 were generalized, 5 were ocular. Six of 11 patients whose anti-AchR antibody was negative were also examined for Anti-MusK antibody. AntiMusk antibody was positive in $3(10.34 \%)$ of these 6 patients. These 3 Anti- AchR and Anti- MuSK negative patients were evaluated as "seronegative". When thymus conditions were examined, thymoma in $3(10.34 \%)$, thymus hyperplasia in $6(20.69 \%)$, no thymus gland in 19 patients $(65.52 \%)$, and normal thymus gland in 1 patient $(3.45 \%)$ was found. It was learned that $5(17.24 \%)$ of the patients had a history of thymectomy ( 3 of them were in the group of patients with thymic hyperplasia and 2 of them were in the thymoma group).

Twenty-two of the 29 patients included in the study were using pyridostigmine bromide $(75.86 \%)$. The average daily dose of pyridostigmine bromide used during the tests was calculated to be $174 \pm$ 126.39 milligrams $(60-360 \mathrm{mg})$. The tests were performed to drug user patients at the end of the 
Table 1. Comparison of SSR data in patient and control groups

\begin{tabular}{|llll|}
\hline & $\begin{array}{l}\text { Patient group } \\
(\mathrm{n}=29)\end{array}$ & $\begin{array}{l}\text { Control } \\
\text { group }(\mathrm{n}=30)\end{array}$ & P value \\
\hline SSR incidence & $28 / 29(\% 96.6)$ & $30 / 30(\% 100)$ & 0.230 \\
SSR initial latency $(\mathrm{ms})$ & $1.44 \pm 0.33$ & $1.53 \pm 0.19$ & 0.222 \\
SSR amplitude $(\mathrm{mV})$ & $2.21 \pm 1.72$ & $2.76 \pm 2.15$ & 0.422 \\
\hline
\end{tabular}

Table 2. Valsalva ratio values according to groups/subgroups

\begin{tabular}{|lll|}
\hline & Valsalva Ratio & P value \\
\hline Total Patient Group & $2.51 \pm 1.18$ & 0.039 \\
Control Group & $3.99 \pm 2.52$ & \\
Patient Group Before Drug Intake & $2.51 \pm 1.18$ & 0.187 \\
Patient Group After Drug Intake & $4.33 \pm 4.59$ & \\
Oculer Group & $2.21 \pm 0.80$ & 0.632 \\
Generalized Group & $2.68 \pm 1.33$ & \\
Early Onset & $2.58 \pm 1.13$ & 0.572 \\
Late Onset & $2.41 \pm 1.29$ & \\
Ach R Ab Positive & $3.01 \pm 1.34$ & 0.033 \\
Ach R Ab Negative & $1.87 \pm 0.43$ & \\
\hline
\end{tabular}

Table 3. Comparison of SSR results before and after drug intake in patient group

\begin{tabular}{|llll|}
\hline & $\begin{array}{l}\text { Before drug } \\
\text { intake }\end{array}$ & $\begin{array}{l}\text { After drug } \\
\text { intake }\end{array}$ & P value \\
\hline SSR initial latency $(\mathrm{ms})$ & $1.51 \pm 0.20$ & $1.53 \pm 0.21$ & 0.702 \\
SSR amplitude $(\mathrm{mV})$ & $2.11 \pm 1.68$ & $1.80 \pm 1.60$ & 0.030 \\
\hline
\end{tabular}

longest period of drug-free time and the mean duration for this was calculated as $11.16 \pm 5.78$ hours (4-24 hours).

The SSR and RRIV results, which assessments were done before the intake of medications, were compared between the patient and the control group. There was no significant difference between the patient and the control groups' SSR results (Table 1). The RRIV increased in both groups during hyperventilation as expected, but the rise was better in the control group $(\mathrm{p}=0.006)$. Valsalva ratio was calculated as shown in Table 2.

The SSR results were compared before drug intake and afterward in 22 patients; there were no significant differences in latencies of SSR $(\mathrm{p}=$ 0.702 ) while amplitudes were lower thereafter drug intake $(\mathrm{p}=0.030)$ (Table 3). There was no significant difference in RRIV and Valsalva ratio for this statement. In the measurement of RRIV, there was no statistically significant difference between the pre and post-drug periods in the resting values, the mean R-R interval time during the hyperventilation was prolonged in the post-drug period, but no statistical significance was found $(\mathrm{p}=0.060)$.

When the SSR results were correlated between the total daily dose of pyridostigmine, the duration of pyridostigmine intake and the application of the test no significant difference was observed between amplitude, dose, and duration $(\mathrm{p}=0.117$ and $p=0.234$, respectively). There was no significant difference between the total daily dose of pyridostigmine and SSR latency $(\mathrm{p}=0.786)$. There was no significant difference in SSR values according to the daily total dose of acetylcholinesterase inhibitors; but as much as time went by after drug administration, prolonged SSR latencies were obtained $(\mathrm{p}=0.043)$.

In the correlation between the duration of pyridostigmine intake and test implementation, it was observed that the percentage of RRIV significantly increased during rest as the time without pyridostigmine prolonged $(\mathrm{p}=0.038)$.

The comparison of SSR and RRIV results obtained from ocular and generalized MG patients showed no significant difference $(p>0.005)$.

The amplitudes of SSR were lower in elderly $(p=0.025)$. The mean age $(37.58 \pm 9.33)$ of early onset MG patients was younger (late onset 62.41 \pm 7.60). Favorable with these statements, SSR was found to have shorter latency $(1.36 \pm 0.39 / 1.56 \pm 0.14 \mathrm{~ms})(\mathrm{p}$ $=0.027)$ and higher amplitude $(2.89 \pm 1.93 / 1.25 \pm$ $0.62 \mathrm{mV})(\mathrm{p}=0.012)$ in the early onset group when compared with the late onset group. No statistically significant difference was found between the two groups in the RRIV results and the Valsalva ratio (p $>0.05)$.

There was no significant difference between SSR latencies (positive 1.43 \pm 0.16 / negative $1.43 \pm$ $0.50 \mathrm{~ms}$ ) and amplitudes (positive $2.31 \pm 1.79 /$ negative $1.80 \pm 1.54 \mathrm{mV}$ ) between the AchR antibody positive and negative patients $(\mathrm{p}=0.158$ and $\mathrm{p}=$ 0.350 , respectively). Also, no statistically significant difference was found between the positive and negative groups in the percentages of RRIV ( $p=$ 0.856 and $p=0.775$ ) measured at rest and hyperventilation. Contrary to these, the Valsalva ratio was lower in the Ach $\mathrm{R}$ antibody negative group (Table 2).

\section{Discussion}

Myasthenia Gravis is an autoimmune disorder caused by antibodies. In the course of autoimmune diseases, the role of the ANS is little known. The immune system can affect both sympathetic and 
parasympathetic components of ANS with different antibodies in various organs and tissues ${ }^{21}$. The common target antigen of MG and autoimmune autonomic ganglionopathy is AchR. In this study, a subclinical parasympathetic dysfunction was found in MG patients. Furthermore, pyridostigmine has been shown to have a non-cumulative peripheral sympathetic cholinergic effect on ANS tests.

In the literature, there are some case reports and few studies investigating autonomic functions in MG patients. It was noted that these cases were mostly with generalized involvement. According to our results, it was not possible to mention such a distinction between ocular and generalized patients.

As mentioned in the study of Benjamin et al., myasthenic crisis has autonomic dysfunction involving multiple organ systems. Increased latency of parasympathetic reflexes is suggested ${ }^{22,23}$. Since autonomic dysfunction can lead to cardiac arrhythmias and even sudden death, it is of major importance to be aware of this association and to properly diagnose and treat these patients ${ }^{23}$. Furthermore, the idea that the presence of possible subclinical dysautonomia in MG patients may increase mortality during myasthenic and cholinergic crisis periods has led us to conduct this study.

The SSR test evaluates peripheral sympathetic cholinergic function via sympathetic sudomotor fibers that innervate the sweat glands ${ }^{24,25}$. The data of SSR results we obtained were similar to those of Shukla et al. In the mentioned study, only two out of 61 patients had the absence of SSR, which did not create also statistical significance ${ }^{26}$. These results suggest that there is no sympathetic system involvement that may lead to impairment in SSR tests in MG patients.

In our study, the results of RRIV and Valsalva ratios suggest that there may be a subclinical involvement of the parasympathetic nervous system in MG patients. In the study of Shukla et al., no significant difference was observed between the patient and the control groups on tests of parasympathetic function (Valsalva ratio, RRIV). It was thought that these effects could also partially be due to pyridostigmine, which all patients were receiving. On the orthostatic tests, patients showed a rise in heart rate, systolic and diastolic blood pressure, as did controls, however, the rate and the duration of the rise were significantly higher than in the controls $(\mathrm{p}<0.01)$. A similar difference between patients and controls, in the rate of rising of these parameters, was observed on the isometric handgrip test. The results were interpreted as sympathetic hyperreactivity in MG patients ${ }^{26}$. In the study of Douchet et al., findings indicating vagal tone decrease were obtained. The absence of bradycardia at night and an increase in mean non-statistically significant heart rate were found in MG patients. The absence of bradycardia was thought to be a modification to an overactive vagal tone. Three hypotheses have been proposed for low vagal tonus formation: antibodies in the ANS affecting nicotinic receptors, respiratory impairment, and desensitization of Ach $\mathrm{R}^{27}$. There are also studies suggesting the contrary to these results. In the study of Stoica et al., impaired norepinephrine response in forearm ischemia, exercise, orthostatic norepinephrine and epinephrine responses tests indicated sympathetic deficits. Achieving normal epinephrine response in these patients was considered as a compensatory mechanism resulting from a sympathetic deficit. According to the authors, this noradrenergic deficit in myasthenic patients is due to cholinergic hyperreactivity ${ }^{28}$. However, the results of the study by Puneeth et al. were indicative of significant parasympathetic deficiency and minimal sympathetic deficiency. So they interpreted that in MG the cholinergic transmission is affected more diffusely than previously thought ${ }^{29}$. There is also a study investigating the role of the sympathetic part of the ANS in the pathogenesis of MG by biochemical methods. In this study, the improvement of clinical findings of $\mathrm{MG}$ with the administration of a sympathomimetic agent revealed the link between $\mathrm{MG}$ and the sympathetic nervous system ${ }^{30}$.

In this study, SSR and RRIV tests, which are the most common electrophysiological studies that test the autonomic nervous system, were used because they are easy to apply and repeatable. The predictive value of heart rate variability alone is modest, but the combination with other techniques substantially improves its positive predictive accuracy over a clinically important range of sensitivity $(25 \%$ to $75 \%$ ) for cardiac mortality and arrhythmic events ${ }^{31}$. In the study of Shahani et al., adult SSR values were found highly specific with a $0 \%$ false-positive rate $^{14}$. As a limitation of our study, we predict that large prospective longitudinal studies are needed to evaluate the sensitivity, specificity, and predictive accuracy of combined testing.

Considering that the effect of pyridostigmine bromide reached maximum level within 1-2 hours and the half-life lasted for 3-4 hours ${ }^{32}$, the tests of the patients were compared with the shots during the drug-free period. Thus, it was aimed to minimize the limitation of pyridostigmine intake that Shukla et al. pointed out in their study. Acetylcho- 
line esterase inhibitors are known to act by increasing the concentration of acetylcholine in the synaptic cleft. They perform these effects through nicotinic and muscarinic cholinergic receptors and as well as neuromuscular junction autonomous ganglia $^{30}$. Acetylcholinesterase inhibitors produce improvement in autonomic functions, just as in motor weakness ${ }^{23,33}$. Shukla et al. reported that the abnormal heart rate dynamics also reverted to normal after administration of pyridostigmine ${ }^{26}$, and Vernino et al. reported improvement in gastrointestinal symptoms after pyridostigmine ${ }^{6}$. It was thought that the decrease in the amplitude of SSR after intake of pyridostigmine was caused by its peripheral sympathetic cholinergic effect ${ }^{24,25}$. In the RRIV test, the increase after drug intake showed that pyridostigmine improved cholinergic functions in MG patients, although it did not reach statistical significance. Chronic use of acetylcholine esterase inhibitors is thought to cause drug-mediated vagotonia in $\mathrm{MG}$ patients $^{30}$. The results of our study suggest that pyridostigmine has an effect on the sympathetic system and there is no cumulative effect on the ANS. However, the prolongation of SSR latency after the disappearance of drug effects suggested the possibility of sympathetic dysfunction in MG patients.

Antibodies that disrupt the transmission of the neuromuscular junction in MG are specific for muscle's nicotinic $\operatorname{AchR}^{34,35}$. It has been shown that monoclonal antibodies against the main immunogenic site in mice with similar specificity to the majority of AchR antibodies in patients with MG bind to the AchR subunits in the peripheral ganglion and adrenal medulla ${ }^{36}$. From this point of view, the presence of cross-reactivity between neuronal and muscle AchR subunits should be investigated. In AchR-positive MG patients, the presence of autonomic dysfunction could be the result of this cross-reactivity ${ }^{37}$. Although the number of patients included in our study was small, the Valsalva ratio was lower in the AchR antibody negative group, suggesting that there might be a parasympathetic dysfunction in this group. According to the literature, most MG patients with autonomic dysfunction are positive in terms of muscle AchR antibody, which is not consistent with our results ${ }^{6,37}$. Nikoli et al. confirmed the most pronounced autonomic failure in thymoma-associated MG patients ${ }^{22}$. Nevertheless, they also had found mild parasympathetic abnormalities in AchR-positive thymoma negative and MuSK-positive MG patients. Due to the limited number of patients in our study, we could not evaluate them according to thymus status. Since there is no definite explanation for these find- ings yet, a completely new research field has appeared, different antibodies that may cause autonomic involvement in MG patients should be investigated.

With aging, several changes occur in ANS. Plasma norepinephrine levels are elevated due to increased release from sympathetic nerve endings and decreased synaptic reuptake ${ }^{38}$. Heart rate response to $\beta$-adrenergic activation decreases due to the down-regulation of $\beta$ receptors with high norepinephrine levels and a decrease in the number of receptors ${ }^{39}$. With a decrease in parasympathetic tonus in old age, the response to hyperventilation and Valsalva maneuvers for RRIV tests were shown to be decreased ${ }^{40,41}$. In our study, parasympathetic system responses decreased with increasing age similarly. In a study conducted by Drory and Korczyn including 100 healthy individuals, SSR response was obtained in all subjects under 60 years of age. Again in the same study, it was noted that there was a significant decrease in SSR amplitude in both upper and lower extremities with increasing age $\mathrm{e}^{42}$. Our data was also consistent with the literature. It was observed that the change in SSR tests was age-dependent and there was no difference between onset age of disease when an ageadjusted correction was made.

Although with some limitations like low patient numbers, finally the findings of the present study showed us that both ocular and generalized MG patients have a subclinical parasympathetic abnormality. Parasympathetic abnormality may become important when MG patients go under any surgery like thymectomy or during a crisis and could account for fluctuations in vital parameters like blood pressure or heart rate. Large prospective longitudinal studies are needed to evaluate autonomic dysfunction in MG patients with combined testing to confirm the presence of subclinical parasympathetic dysfunction. Changes in ANS with aging are also seen in electrophysiological tests. The late disease onset group is older, while the early onset MG patients have a younger age average. So, the changes of ANS in the elderly are regardless of the age at disease onset, the difference is because of aging.

This study also suggests, that pyridostigmine has a peripheral sympathetic cholinergic noncumulative effect on these autonomic tests. Another limitation of our study is that we had to assess autonomic functions while patients were receiving pyridostigmine which can increase both sympathetic and parasympathetic responses by increasing ganglionic transmission. The role of acetylcholinesterase inhibitors needs a prospective evaluation in 
further controlled studies with MG patients who are on versus who are not on these drugs. The presence of more prominent cholinergic dysfunction in the AchR antibody negative group suggested the presence of different antibodies that could lead to ANS involvement in MG patients and should be investigated.

\section{ACKNOWLEDGEMENTS}

None of the authors has any conflict of interest to disclose any sources of fundi.

We confirm that we have read the Journal's position on issues involved in ethical publication and affirm that this report is consistent with those guidelines.

\section{REFERENCES}

1. Kumar V, Cotran R, Robins S. The Musculoskeletal system: Myasthenia gravis. Basic Pathology. 5. Basım. W.B. Saunders Co. Bölüm 1992;21:698-9.

2. Adams RD, Victor M. Myasthenia gravis and episodic forms of muscular weakness. Principles of Neurology. 5. Bask1. Bölüm 1993;53:1252-62.

3. Deymeer F. Myastenia Graviste Tedavi. Turkiye Klinikleri J Int Med Sci 2005;1(22):38-43.

4. Younger DS, Worrall BB, Penn AS. Myasthenia gravis: historical perspective and overview. Neurology 1997;48:S1-S7. https://doi.org/10.1212/WNL.48.Suppl_5.1S

5. Merigglioli MN. Myastenia gravis: Immunopathogenesis, diagnosis, and management. Contınuum 2009;15(1):35-62. https://doi.org/10.1212/01.CON.0000300007.56974.b7

6. Vernino $S$, Cheshire Wp, Lennon VA. Myastenia gravis with autoimmune autonomic neuropathy. Autonomic Neuroscience 2001;88:187-92. https://doi.org/10.1016/S1566-0702(01)00239-9

7. Rakocevic G, Barohn R, McVey AL, Damjanov I, Morte $P D$, Vernino $S$, et al. Myasthenia gravis, thymoma, and intestinal pseudo-obstruction: a case report and review. J Clin Neuromuscul Dis 2003;5(2):93-5. https://doi.org/10.1097/00131402-200312000-00004

8. Anderson NE, Hutchinson DO, Nicholson GJ, Aitcheson F, Nixon JM. Intestinal pseudo-obstruction, myasthenia gravis, and thymoma. Neurology 1996;47(4):985-7. https://doi.org/10.1212/WNL.47.4.985

9. Senda Y, Sugimura K, Koike Y, Matsuoka Y, Takahashi A. Concurrence of acute autonomic and sensory neuropathy and myasthenia gravis - a case report and pathogenetic considerations. Rinsho Shinkeigaku 1989;29(3):332-5.

10. Vernino $S$, Low PA, Fealey RD, Stewart JD, Farrugia G, Lennon VA. Autoantibodies to ganglionic acetylcholine receptors in autoimmune autonomic neuropathies. New Engl J Med 2000;343:847-55. https://doi.org/10.1056/NEJM200009213431204

11. Lennon VA, Ermilov LG, Szurszewski JH, Vernino S. Immunization with neuronal nicotinic acetylcholine receptor induces neurological autoimmune disease. J Clin Invest 2003;111:907-13. https://doi.org/10.1172/JCI200317429

12. Mycek MJ, Harvey RA, Champe PC, Oktay S. Otonom sinir sistemine etkili ilaçlar. Pharmacology. 2nd ed. Nobel. İstanbul: Lippincott's Illustrated Review; 1998. p. 27-80.

13. Shahani TB, Day TJ, Cros D, Khalil N, Kneebone CS. RR interval variation and the sympathetic skin response in the assessment of autonomic function in peripheral neuropathy. Arch Neurol 1990;47:659-64.

https://doi.org/10.1001/archneur.1990.00530060069021

14. Shahani BT, Halperin JJ, Boulu P, Cohen J. Sympathetic skin response-a method of assessing unmyelinated axon dysfunction in peripheral neuropathies. Journal of Neurology, Neurosurgery, and Psychiatry 1984;47:536-42. https://doi.org/10.1136/jnnp.47.5.536

15. Drake ME, Andrews JM, Castleberry CM. Electrophysiological assessment of autonomic function in epilepsy. Seizure 1998;7:91-6. https://doi.org/10.1016/S1059-1311(98)80047-2 https://doi.org/10.1016/S1059-1311(98)80062-9

16. Ulvi H, Yoldas R, Yigiter R, Mungen B. R-R interval variation and the sympathetic skin response in the assessment of the autonomic nervous system in leprosy patients. Acta Neurol Scand 2003;107:42-9. https://doi.org/10.1034/j.1600-0404.2003.01307.x

17. Muslumanoglu L, Akyuz G, Aki S, Karsidag S, Us O. Evaluation of Autonomic nervous system functions in poststroke patients. Am J Phys Med Rehabil 2002;81:721-5. https://doi.org/10.1097/00002060-200210000-00001

18. Karatas GK, Onder M, Meray J. Autonomic nervous system involvement in Behçet's disease. Rheumatol Int 2002; 22:155-9. https://doi.org/10.1007/s00296-002-0220-0

19. Ulas UH, Unlu E, Hamamcioglu K, Odabasi Z, Cakci A, Vural $O$. Dysautonomia in fibromyalgia syndrome: sympathetic skin responses and RR interval analysis. Rheumatol Int 2006;26(5):383-7. https://doi.org/10.1007/s00296-005-0007-1

20. Ravits $J M$. Autonomic nervous system testing. Muscle \& Nerve 1997;48:919-37. https://doi.org/10.1002/(SICI)1097-4598(199708)20:8 $<919:$ :AID-MUS1>3.0.CO;2-9

21. Elies R, Ferrari I, Wallukat G, Lebesgue D, Chiale P, Elizari $M$, et al. Structural and functional analysis of the B cell epitopes recognized by anti-receptor autoantibodies in patients with Chagas' disease. J Immunol 1996;157(9):4203-11.

22. Nikoli A, Peri S, Niši T, Popovi S, Ili M, Rako evi V, et $a l$. The presence of dysautonomia in different subgroups of myasthenia gravis patients. J Neurol 2014;261:2119-27. https://doi.org/10.1007/s00415-014-7465-x

23. Benjamin RN, Aaron S, Sivadasan A, Devasahayam S, Sebastin A, Alexander $M$. The Spectrum of Autonomic Dysfunction in Myasthenic Crisis. Ann Indian Acad Neurol 2018;21(1):42-8.

24. Akyüz G, Leblebiciler MA. Otonom Sinir Sistemi Anatomisi ve de erlendirilmesi. Türk Fiz Tıp Rehab Derg 2012; $58(1): 1-5$.

25. Evlice AT. Obstruktif uyku apne sendromunda otonomik disfonksiyonun de erlendirilmesi. Arşiv kaynak tarama dergisi 2012;21(2):109-21.

26. Shukla G, Gupta S, Goyal V, Singh S, Srivastava A, Behari M. 
Abnormal sympathetic hyper-reactivity in patients with myastenia gravis: A prospective study. Clin Neurol and Neurosurg 2012;2953:1-8.

27. Douchet MP, Quiring E, Bronner F, Vi-Fane R, Messier M, Chauvin $M$, et al. Paradoxal lowering of parasympathetic indices in myasthenic patients. Arch Mal Coeur Vaiss 1999;92(6):711-7.

28. Stoica E, Enulescu $O$. Deficiency of sympathetic nervous system function in myasthenia. J Auton Nerv Syst 1992; 38(1):69-76. https://doi.org/10.1016/0165-1838(92)90218-6

29. Puneeth CS, Chandra SR, Yadav R, Sathyaprabha TN, Chandran $S$. Heart rate and blood pressure variability in patients with myasthenia gravis. Ann Indian Acad Neurol 2013;16(3):329-32. https://doi.org/10.4103/0972-2327.116912

30. Lantsova VB, Sepp EK, Kozlovsky AS. Role sympathetic autonomic nervous system in the regulation of immune response during myasthenia. Bull Exp Biol Med 2011;151(3): 353-5. https://doi.org/10.1007/s10517-011-1328-6

31 . Heart rate variability Standards of measurement, physiological interpretation, and clinical use Task Force of The European Society of Cardiology and The North American Society of Pacing and Electrophysiology. Membership of the Task Force listed in the Appendix. European Heart Journal 1996;17:354-81.

32. Myasthenia Gravis Foundation of America, Inc. Pyridostigmine (Mestinon®). New York. 2010 (www.myasthenia.org).

33. Lepore FE, Sanborn GE, Slevin JT. Pupillary dysfunction in myasthenia gravis. Ann Neurol 1979;6:29-33. https://doi.org/10.1002/ana.410060107

34. Drachman DB, Adams RN, Josifek LF, Self SG. Functional activities of autoantibodies to acetylcholine receptors and the clinical severity of myasthenia gravis. New England Journal of Medicine 1982;307:769-75.

https://doi.org/10.1056/NEJM198209233071301

35. Drachman DB. Myasthenia gravis. N Engl J Med 1994; 330(25):1797-810. https://doi.org/10.1056/NEJM199406233302507

36. Wang F, Gerzanich V, Wells GB, Anand R, Peng X, Keyser K, et al. Assembly of human neuronal nicotinic receptor $\alpha 5$ subunits with $\alpha 3, \beta 2$, and $\beta 4$ subunits. J Biol Chem 1996;271 (30):17656-65. https://doi.org/10.1074/jbc.271.30.17656

37. Vernino $S$, Hopkins $S$, Wang Z. Autonomic ganglia, acetylcholine receptor antibodies, and autoimmune ganglionopathy. Auton Neurosci 2009;146(1-2):3-7. https://doi.org/10.1016/j.autneu.2008.09.005

38. Morrow LA, Linares OA, Hill TJ, Sanfield JA, Supiano MA, Rosen $S G$, et al. Age differences in the plasma clearance mechanisms for epinephrine and norepinephrine in humans. J Clin Endocrinol Metab 1987;65(3):508-11. https://doi.org/10.1210/jcem-65-3-508

39. Brodde OE, Zerkowski HR, Schranz D, Broede-Sitz A, Michel-Reher M, Schäfer-Beisenbusch E, et al. Age-dependent changes in the $\beta$-adrenoceptor-G-protein(s)-adenylyl cyclase system in human right atrium. J Cardiovasc Pharmacol 1995;26(1):20-6. https://doi.org/10.1097/00005344-199507000-00004

40. Gautschy B, Weidmann P, Gnädinger MP. Autonomic function tests as related to age and gender in normal man. Klin Wochenschr 1986;64(11):499-505. https://doi.org/10.1007/BF01713056

41. Jennings JR, Mack ME. Does aging differentially reduce heart rate variability related to respiration? Exp Aging Res 1984;10 (1):19-23. https://doi.org/10.1080/03610738408258536

42. Drory VE, Korczyn AD. Sympathetic skin response: age effect. Neurology 1993;43(9):1818-20. https://doi.org/10.1212/WNL.43.9.1818 